JAMP: Jurnal Adminitrasi dan Manajemen Pendidikan

Volume 2 Nomor 4 Desember 2019, Hal : 247-257

Tersedia Online di http://journal2.um.ac.id/index.php/jamp/

ISSN 2615-8574 (online)

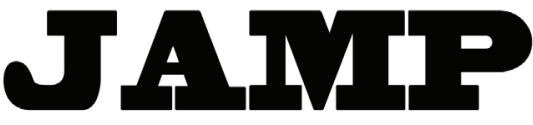

\title{
VALIDITAS DAN RELIABILITAS ANGKET KETERAMPILAN MANAJERIAL MAHASISWA
}

\author{
Imam Gunawan ${ }^{1}$ \\ Djum Djum Noor Benty ${ }^{2}$ \\ Desi Eri Kusumaningrum ${ }^{3}$ \\ Raden Bambang Sumarsono ${ }^{4}$ \\ Dika Novita Sari ${ }^{5}$ \\ Firda Dwi Pratiwi ${ }^{6}$ \\ Sari Oktavia Ningsih ${ }^{7}$ \\ Lim Kim Hui ${ }^{8}$
}

\author{
1,2,3,4,5,6,7 Universitas Negeri Malang, Jalan Semarang 5 Malang 65145 \\ ${ }^{8}$ Hankuk University of Foreign Studies, Seoul, South Korea \\ Email: imam.gunawan.fip@um.ac.id
}

\begin{abstract}
Managerial skills is an important ability that must be possessed by students. This skills is a provision for students to live in the general public. Higher education should prepare students to have reliable managerial skills. Therefore, there needs to be an instrument that helps educational institutions to measure the managerial skills of their students. This article presents an analysis of the validity and reliability of the student managerial skills questionnaire. The respondents of this study were 35 students. Test the validity of using the Product Moment Correlation formula developed by Pearson. Test reliability using the Cronbach's Alpha formula. The validity test results showed that of the 18 items developed, there were 17 valid items, with a value of $\alpha \leq 0.05$. The reliability test results were subject to 17 valid items, showing $r_{\text {alpha }}=0.864>r_{\text {table }}=0.468$; and all Cronbach's Alpha if Deleted Items $>0.468$. So it was concluded that the instrument was reliable.
\end{abstract}

Keywords: validity, reliability, managerial skills, students

Abstrak: Keterampilan manajerial merupakan kemampuan penting yang harus dimiliki oleh mahasiswa. Kemampuan tersebut merupakan bekal mahasiswa untuk hidup di masyarakat umum. Perguruan tinggi sudah seyogyanya menyiapkan mahasiswa untuk memiliki keterampilan manajerial yang andal. Oleh sebab itu, perlu ada instrumen yang membantu lembaga pendidikan untuk mengukur keterampilan manajerial para peserta didiknya. Artikel ini menyajikan analisis validitas dan reliabilitas terhadap instrumen angket keterampilan manajerial mahasiswa. Responden penelitian ini adalah 35 mahasiswa. Uji validitas dengan menggunakan formula Korelasi Product Moment yang dikembangkan oleh Pearson. Uji reliabilitas dengan menggunakan formula Cronbach's Alpha. Hasil uji validitas menunjukkan dari 18 item yang dikembangkan, ada 17 item yang valid, dengan nilai $\alpha \leq 0,05$. Hasil uji reliabilitas dikenakan pada 17 item yang valid, menunjukkan $r_{\text {alpha }}=0,864>r_{\text {tabel }}=0,468$; dan semua Cronbach's Alpha if Item Deleted $>0,468$. Sehingga disimpulkan bahwa instrumen tersebut reliabel.

Kata kunci: validitas, reliabilitas, keterampilan manajerial, mahasiswa

Kepemimpinan mahasiswa akan lebih baik manakala diikuti dengan keterampilan manajerial yang baik dalam diri mahasiswa. Keterampilan manajerial digunakan oleh seorang pemimpin dalam menjalankan 
organisasi. Katz (2017) mengemukakan keterampilan manajerial yang harus dimiliki oleh seorang pemimpin adalah keterampilan teknis, keterampilan hubungan manusia, dan keterampilan konseptual. Keterampilan teknis adalah keterampilan menjalankan pekerjaan sesuai dengan tugas yang diembannya. Keterampilan teknis ini harus dimiliki pemimpin pada level bawah. Keterampilan konseptual berkaitan dengan kemampuan seseorang dalam memikirkan perencanaan dan strategi organisasi. Keterampilan ini harus dimiliki oleh pemimpin pada level atas. Keterampilan hubungan manusia merupakan keterampilan yang berkaitan dengan cara berkomunikasi dengan orang lain. Keterampilan ini semua orang pemimpin harus memiliki. Keterampilan manajerial mendukung keefektifan seorang pemimpin dalam mempengaruhi para anggotanya untuk bekerja dengan baik.

Seorang pemimpin dalam organisasi memerlukan beberapa keterampilan dalam menjalankan roda organisasi. Keterampilan manajerial adalah keterampilan atau kualitas yang dicari organisasi dalam diri seorang pemimpin untuk mengelola organisasi. Keterampilan manajerial adalah keterampilan untuk mengatur, mengoordinasikan, dan menggerakkan para bawahan ke arah pencapaian tujuan yang telah ditentukan organisasi. Keterampilan manajerial adalah kemampuan seseorang dalam mengelola sumber daya organisasi berdasarkan kompetensi yang ditetapkan dalam rangka mencapai tujuan yang ditentukan (Kholiq, 2011). Keterampilan manajerial tidak akan begitu saja muncul dan langsung dimiliki oleh seseorang. Kemampuan ini lahir dari suatu proses panjang yang terjadi secara perlahan melalui proses pengamatan dan pembelajaran.

Sehingga untuk memiliki kemampuan ini, seseorang perlu berupaya, ada laku tindakan yang harus dilaksanakan, dan terus belajar dengan keras. Kehidupan nyata adalah kelas yang nyata untuk mengembangkan kemampuan ini. Seorang pemimpin dalam organisasi yang berukuran besar, kesempatan untuk mengadakan kontak dengan seluruh bawahan relatif sangat kecil. Lebih-lebih dalam organisasi yang besar dengan ruang lingkup operasinya berskala nasional atau internasional. Seorang pimpinan, dituntut untuk memiliki keterampilan manajerial, sehingga kegiatan mengintegrasikan, mengoordinasikan, dan menggerakkan para bawahan dalam ruang lingkup usaha yang besar, dapat dilakukan dengan baik. Jika mengacu pada berbagai literatur, maka dapat diketahui bahwa ada lima jenis keterampilan manajerial, yaitu: (1) keterampilan teknis; (2) keterampilan konseptual; (3) keterampilan interpersonal dan komunikasi; (4) keterampilan pengambilan keputusan; dan (5) keterampilan diagnostik dan analitik (Katz, 2017; Schein, 2017; Burhanuddin, 1994).

Keterampilan manajerial adalah istilah yang mengacu pada keterampilan yang dibutuhkan (kompetensi) manajer. Secara khusus, keterampilan berikut termasuk: (1) perencanaan, untuk mengetahui teknik perencanaan dan dapat menerapkannya dalam praktik; (2) pengorganisasian, untuk mengetahui teknik pengorganisasian dan dapat menerapkannya; (3) manajemen orang, kemampuan untuk mengelola orang, ini adalah keterampilan keras yang khas, seperti alokasi kerja, pemantauan; (4) kepemimpinan, kemampuan untuk memimpin orang, ini adalah soft skill khas untuk memotivasi, menginspirasi, dan melatih; (5) berkomunikasi, untuk menjadi komunikator yang baik; (6) pengambilan keputusan, untuk mengetahui teknik-teknik pengambilan keputusan dan dapat menerapkannya secara praktis; (7) pemecahan masalah, untuk dapat memecahkan masalah. Sangat penting bahwa keterampilan manajerial dapat diperoleh sebagian dalam pendidikan manajemen yang lebih tinggi dan sebagian diperoleh dengan berlatih.

Perencanaan bermanfaat bagi organisasi untuk memulai dan untuk mencapai berhasil. Perencanaan itu penting dalam setiap tahap organisasi. Perencanaan bisa rencana jangka pendek, jangka menengah, atau jangka panjang. Ini melibatkan pemangku kepentingan dan pembuat keputusan lain dari organisasi yang berkumpul, menentukan situasi saat ini, menimbang dan mengevaluasi berbagai pilihan, dan memutuskan alternatif yang disajikan. Ketika organisasi merencanakan sebelumnya, semuanya akan dipelajari dengan cermat dan terperinci, sehingga memastikan eksekusi yang sukses. Tanpa perencanaan yang matang, organisasi akan berisiko.

Salah satu keterampilan manajerial yang paling penting setelah perencanaan adalah pengorganisasian. Setelah menentukan apa yang harus dilakukan selama tahap perencanaan, seseorang akan tahu apa yang harus dilakukan selanjutnya. Organisasi perlu mengidentifikasi berbagai tugas dan tanggung jawab, 
mengatur orang-orang, menugaskan mereka tugas-tugas mereka dan menentukan sumber daya lain dari organisasi yang diperlukan untuk membuat rencana menjadi kenyataan. Pengorganisasian menyediakan rantai komando, penugasan tanggung jawab dan mencapai kontrol yang tepat terhadap organisasi. Seorang manajer yang baik mengatur dengan sukses dengan mengomunikasikan rencana secara efektif. Sementara perencanaan berurusan dengan hal-hal yang perlu dilakukan, mengorganisasikan kesepakatan dengan bagaimana membuat rencana itu berhasil operasional.

Setelah pengorganisasian datang mengarahkan di mana pemimpin sekarang akan memimpin orang tentang apa yang harus dilakukan untuk melaksanakan rencana tersebut. Sementara perencanaan dan pengorganisasian menggunakan pemikiran, mengarahkan mengarahkan pemikiran ini ke dalam tindakan. Ini adalah tahap implementasi. Organisasi memberi tahu orang-orang yang ada dalam organisasi tentang apa yang harus dilakukan sehingga maksud dan tujuan organisasi terpenuhi. Organisasi perlu menekankan kepada mereka sekali dan untuk semua tujuan organisasi sehingga mereka akan memahaminya dengan benar. Organisasi perlu memberi tahu mereka tentang pentingnya mereka dalam mencapai tujuan-tujuan ini. Organisasi juga perlu memastikan bahwa mereka memiliki semua yang mereka butuhkan untuk melaksanakan rencana tersebut. Untuk mengarahkan secara efektif, jangan pernah duduk dan memberi perintah. Alih-alih, memimpin dalam melakukan sesuatu dan mengawasi serta membantu orang-orang dalam tugas-tugas mereka. Ini akan mendorong orang-orang untuk bekerja lebih keras.

Tindakan mengendalikan juga merupakan keterampilan manajemen yang diperlukan. Organisasi perlu mencapai kendali atas orang-orang untuk mencapai misi organisasi termasuk kebutuhan untuk berurusan dengan orang-orang yang sulit serta memotivasi karyawan. Untuk melakukan ini, organisasi perlu menetapkan standar kinerja sehingga orang-orang akan tahu bagaimana kinerja mereka dan pemimpin akan memiliki dasar untuk mengevaluasi pekerjaan mereka. Organisasi juga perlu memantau dan mengevaluasi kinerja dan memberikan umpan balik atas temuan. Organisasi dapat memberikan kutipan kepada mereka yang melakukan pekerjaannya dengan baik atau yang melebihi hasil mereka. Ketika organisasi memiliki keterampilan manajerial yang baik, maka organisasi akan berada di tangan yang baik. Pengendalian ini bermanfaat bagi organisasi untuk memastikan bahwa apa yang dilaksanakan sesuai dengan program yang telah dirancang untuk mencapai visi, misi, dan tujuan organisasi.

Keterampilan adalah kemampuan individu untuk menerjemahkan pengetahuan ke dalam tindakan. Seorang manajer harus memiliki beragam keterampilan dan kemampuan untuk menjalankan berbagai fungsi manajemen. Meskipun keterampilan melanjutkan semuanya sangat penting, kepentingan relatif masing-masing akan bervariasi sesuai dengan tingkat manajer dalam organisasi. Sebagai contoh, manajer lini pertama umumnya perlu lebih bergantung pada keterampilan teknis dan manusia mereka. Para manajer ini memiliki kontak yang lebih besar dengan pekerjaan yang dilakukan dan orang-orang yang melakukan pekerjaan. Keterampilan digital sama pentingnya di semua tingkat manajemen. Manajer menengah membutuhkan distribusi keterampilan yang lebih merata. Akhirnya, keterampilan konseptual dan diagnostik sangat penting bagi manajer puncak. Tanggung jawab utama manajemen puncak adalah membuat keputusan kunci yang dijalankan atau diimplementasikan di tingkat yang lebih rendah. Ini membutuhkan manajer puncak melihat gambaran besar untuk mengidentifikasi peluang di lingkungan dan mengembangkan rencana strategis untuk memanfaatkan peluang ini.

\section{METODE}

Artikel ini menyajikan hasil uji validitas dan reliabilitas terhadap instrumen angket variabel keterampilan manajerial mahasiswa. Angket disusun sebanyak 18 item pernyataan, yang dikembangkan dari teori Katz (2017); Schein (2017); dan Burhanuddin (1994). Adapun jabaran variabel keterampilan manajerial mahasiswa ditampilkan pada Tabel 1. Angket yang disusun adalah angket tertutup, yakni responden memiliki alternatif jawaban: selalu diberi skor 4; sering diberi skor 3; jarang diberi skor 2; dan tidak pernah diberi skor 1 . Responden penelitian adalah 35 mahasiswa aktivis UKM KSR PMI Unit Universitas Negeri Malang. Penelitian dilaksanakan pada rentang tahun 2019. Uji validitas dengan menggunakan formula Korelasi Product Moment Pearson (Rumus 1). Suatu item valid jika nilai probabilitas $(\alpha)<0,05$ (Gunawan, 2016; Hadi, dkk., 2018; Gunawan, 2013). Uji reliabilitas dengan 
menggunakan Cronbach's Alpha (Rumus 2). Uji validitas dan reliabilitas dengan menggunakan program IBM SPSS Statistics 20. Kriteria instrumen dinyatakan reliabel apabila nilai $r_{\text {alpha }}>r_{\text {tabel }}$, dan nilai $r_{\text {tabel }}$ untuk $\mathrm{N}=35$ adalah 0,468 (Gunawan, 2016; Hadi, dkk., 2018; Gunawan, 2013).

$$
\begin{aligned}
& \mathrm{r}=\frac{N \Sigma \mathrm{XY}-(\mathrm{\Sigma X})(\mathrm{\Sigma Y})}{\sqrt{\left(N \Sigma \mathrm{X}^{2}-(\Sigma \mathrm{X})^{2}\right)\left(N \Sigma \mathrm{Y}^{2}-(\Sigma \mathrm{Y})^{2}\right)}} \\
& \alpha=\frac{N \varepsilon}{\bar{v}+(N-1) \bar{c}}
\end{aligned}
$$

Tabel 1 Jabaran Variabel Keterampilan manajerial Mahasiswa

\begin{tabular}{|lllc|}
\hline \multicolumn{1}{c}{ Variabel } & \multicolumn{1}{c}{ Indikator } & Item \\
\hline Keterampilan manajerial Mahasiswa (X2) & a. Keterampilan teknis & $1,2,3,4$ \\
& b. Keterampilan konseptual & $5,6,7$ \\
& c. & Keterampilan interpersonal dan komunikasi & $8,9,10$ \\
(Katz, 2017; Schein, 2017; Burhanuddin, 1994) & d. & Keterampilan pengambilan keputusan & $11,12,13,14$ \\
& e. & Keterampilan diagnostik dan analitik & $15,16,17,18$ \\
\hline
\end{tabular}

\section{HASIL}

Variabel keterampilan manajerial mahasiswa diukur dengan menggunakan 18 item pernyataan. Berdasarkan hasil uji validitas, diketahui ada 17 item yang valid, dengan nilai $\alpha \leq 0,05$; dan ada 1 item tidak valid, dengan nilai $\alpha>0,05$. Hasil validitas ditampilkan pada Tabel 2. Mengacu pada hasil uji validitas, maka dapat disimpulkan ada 17 item dari 18 item yang dapat digunakan untuk mengukur variabel keterampilan manajerial mahasiswa.

\begin{tabular}{|c|c|c|c|c|}
\hline Item & Pernyataan & $\begin{array}{l}\text { Pearson } \\
\text { Correlation }\end{array}$ & $\begin{array}{l}\text { Sig. } \\
\text { (2-tailed) }\end{array}$ & Keterangan \\
\hline 1 & $\begin{array}{l}\text { Saya melaksanakan tugas organisasi menggunakan perangkat sep- } \\
\text { erti komputer, laptop, ataupun smartphone }\end{array}$ & 0,614 & 0,000 & Valid \\
\hline 2 & $\begin{array}{l}\text { Rencana kegiatan dibuat ketika organisasi akan melaksanakan suatu } \\
\text { agenda }\end{array}$ & 0,547 & 0,001 & Valid \\
\hline 3 & $\begin{array}{l}\text { Rencana anggaran dibuat ketika organisasi akan melaksanakan suatu } \\
\text { kegiatan }\end{array}$ & 0,191 & 0,271 & Tidak Valid \\
\hline 4 & $\begin{array}{l}\text { Saya menyiapkan power point sebagai bahan presentasi ketika ada } \\
\text { rapat organisasi }\end{array}$ & 0,531 & 0,001 & Valid \\
\hline 5 & Saya ikut terlibat dalam penyusunan visi, misi, dan tujuan organisasi & 0,769 & 0,000 & Valid \\
\hline 6 & Saya ikut terlibat dalam penyusunan program kerja organisasi & 0,504 & 0,002 & Valid \\
\hline 7 & $\begin{array}{l}\text { Setiap kegiatan baru yang dilaksanakan organisasi merupakan sentu- } \\
\text { han ide baru dari saya }\end{array}$ & 0,609 & 0,000 & Valid \\
\hline 8 & $\begin{array}{l}\text { Keberadaan saya di organisasi diterima oleh anggota lainnya dengan } \\
\text { penuh kesadaran }\end{array}$ & 0,560 & 0,000 & Valid \\
\hline 9 & $\begin{array}{l}\text { Jalinan komunikasi saya dengan anggota organisasi berjalan dengan } \\
\text { baik }\end{array}$ & 0,655 & 0,000 & Valid \\
\hline 10 & $\begin{array}{l}\text { Sebagai seorang pemimpin organisasi, saya dapat memberikan mo- } \\
\text { tivasi kepada anggota organisasi }\end{array}$ & 0,732 & 0,000 & Valid \\
\hline 11 & $\begin{array}{l}\text { Setiap keputusan organisasi merupakan hasil musyawarah mufakat } \\
\text { organisasi }\end{array}$ & 0,530 & 0,001 & Valid \\
\hline 12 & $\begin{array}{l}\text { Keputusan yang saya ambil mengacu pada upaya pencapaian visi, } \\
\text { misi, dan tujuan organisasi }\end{array}$ & 0,580 & 0,000 & Valid \\
\hline
\end{tabular}

Tabel 2 Hasil Uji Validitas Variabel Keterampilan manajerial Mahasiswa 


\begin{tabular}{|c|c|c|c|c|}
\hline Item & Pernyataan & $\begin{array}{l}\text { Pearson } \\
\text { Correlation }\end{array}$ & $\begin{array}{c}\text { Sig. } \\
\text { (2-tailed) }\end{array}$ & Keterangan \\
\hline 13 & $\begin{array}{l}\text { Keputusan organisasi didasarkan pada hasil analisis peluang dan tan- } \\
\text { tangan organisasi }\end{array}$ & 0,517 & 0,001 & Valid \\
\hline 14 & $\begin{array}{l}\text { Setiap anggota organisasi memiliki hak yang sama untuk mengu- } \\
\text { sulkan alternatif penyelesaian masalah sebagai bahan pengambilan } \\
\text { keputusan organisasi }\end{array}$ & 0,348 & 0,041 & Valid \\
\hline 15 & $\begin{array}{l}\text { Kerangka berpikir yang benar dan baik menjadi acuan dalam peny- } \\
\text { elenggaraan organisasi }\end{array}$ & 0,492 & 0,003 & Valid \\
\hline 16 & $\begin{array}{l}\text { Pengetahuan konseptual untuk menyelesaikan masalah memiliki } \\
\text { kedudukan yang sangat penting dalam organisasi }\end{array}$ & 0,518 & 0,001 & Valid \\
\hline 17 & $\begin{array}{l}\text { Setiap keputusan yang diambil organisasi merupakan hasil diagnosis } \\
\text { dan analisis yang cermat dan teliti terhadap situasi yang dihadapi } \\
\text { oleh organisasi }\end{array}$ & 0,641 & 0,000 & Valid \\
\hline 18 & $\begin{array}{l}\text { Kesediaan informasi yang benar menjadi bahan dalam pengambilan } \\
\text { keputusan }\end{array}$ & 0,473 & 0,004 & Valid \\
\hline
\end{tabular}

Selanjutnya 17 item yang valid, diuji reliabilitasnya. Hasil uji reliabilitas menunjukkan bahwa nilai Cronbach's Alpha sebesar 0,864 seperti ditampilkan pada Tabel 3; dan Cronbach's Alpha if Item Deleted seperti ditampilkan pada Tabel 4. Hasil uji reliabilitas menunjukkan $r_{\text {alpha }}=0,864>r_{\text {tabel }}=0,468$; dan semua Cronbach's Alpha if Item Deleted $>0,468$. Sehingga disimpulkan bahwa instrumen tersebut reliabel. Artinya instrumen tersebut dapat disebut sebagai instrumen yang memiliki tingkat konsistensi tinggi dalam mengukur variabel keterampilan manajerial mahasiswa. Jika mengacu pada hasil uji validitas dan reliabilitas terhadap angket variabel keterampilan manajerial mahasiswa, maka peneliti lain dapat langsung memanfaatkan angket tersebut untuk mengukur variabel keterampilan manajerial mahasiswa.

Tabel 3 Reliability Statistics

\begin{tabular}{cc}
\hline Cronbach's Alpha & N of Items \\
\hline .864 & 17 \\
\hline
\end{tabular}

Tabel 4 Item-Total Statistics

\begin{tabular}{rccccc}
\hline & $\begin{array}{c}\text { Scale Mean if } \\
\text { Item Deleted }\end{array}$ & $\begin{array}{c}\text { Scale Variance if } \\
\text { Item Deleted }\end{array}$ & $\begin{array}{c}\text { Corrected Item- } \\
\text { Total Correlation }\end{array}$ & $\begin{array}{c}\text { Cronbach's Alpha } \\
\text { if Item Deleted }\end{array}$ & Keterangan \\
\hline it1 & 50.03 & 38.911 & .544 & .855 & Reliabel \\
it2 & 50.26 & 39.197 & .444 & .858 & Reliabel \\
it4 & 51.37 & 36.358 & .423 & .863 & Reliabel \\
it5 & 51.03 & 33.852 & .708 & .844 & Reliabel \\
it6 & 50.46 & 37.373 & .401 & .862 & Reliabel \\
it7 & 51.20 & 36.812 & .542 & .854 & Reliabel \\
it8 & 50.37 & 38.770 & .494 & .856 & Reliabel \\
it9 & 50.49 & 37.198 & .575 & .852 & Reliabel \\
it10 & 50.71 & 36.328 & .676 & .847 & Reliabel \\
it11 & 50.14 & 38.597 & .468 & .857 & Reliabel \\
it12 & 50.40 & 38.600 & .535 & .855 & Reliabel \\
it13 & 50.51 & 39.022 & .436 & .858 & Reliabel \\
it14 & 50.17 & 40.205 & .253 & .865 & Reliabel \\
it15 & 50.20 & 39.459 & .448 & .858 & Reliabel \\
it16 & 50.34 & 38.408 & .445 & .858 & Reliabel \\
it17 & 50.26 & 37.961 & .572 & .853 & Reliabel \\
it18 & 50.11 & 38.928 & .423 & .859 & Reliabel \\
\hline
\end{tabular}




\section{PEMBAHASAN}

Keterampilan adalah kemampuan yang diperoleh dan dipelajari untuk menerjemahkan pengetahuan menjadi kinerja. Ini adalah kompetensi yang memungkinkan kinerja menjadi unggul di bidang di mana pekerja memiliki keterampilan yang diperlukan. Semua mahasiswa perlu memiliki keterampilan teknis, interpersonal, konseptual, diagnostik, komunikasi, dan politik (Gunawan, dkk., 2018a; Gunawan, dkk., 2018b; Gunawan, dkk., 2018c). Sementara keterampilan teknis dan diagnostik merujuk pada pengetahuan dan kemampuan memahami proses yang terlibat dan menganalisis masalah dan peluang secara ilmiah, semua keterampilan lain berurusan dengan orang-orang dalam satu bentuk atau lainnya. Keterampilan manusia ini adalah aset paling penting dari setiap manajer yang sukses.

Adalah tugas manajer untuk mencapai tujuan organisasi melalui pemanfaatan sumber daya manusia dan materialnya secara tepat. Namun, karena sumber daya material dari peralatan, modal, fasilitas, informasi, dan sebagainya hanya dapat digunakan oleh manusia, sumber daya manusia adalah aset paling berharga dari organisasi mana pun. Oleh karena itu, seorang manajer harus sangat terampil dalam bidang pemanfaatan sumber daya manusia secara optimal. Seni ini bersifat universal. Dalam setiap jalan kehidupan, keterampilan manusia diperlukan untuk sukses.

Agar berhasil dalam perencanaan, pengorganisasian, memimpin, dan mengendalikan, manajer harus menggunakan berbagai keterampilan. Keterampilan adalah kemampuan untuk melakukan sesuatu dengan mahir. Keterampilan manajerial terbagi dalam tiga kategori dasar: teknis, hubungan manusia, dan keterampilan konseptual (BC Campus, 2019). Tingkat penggunaan setiap jenis keterampilan tergantung pada tingkat posisi manajer. Bidang khusus pengetahuan dan keahlian dan kemampuan untuk menerapkan pengetahuan itu membentuk keterampilan teknis manajer. Mempersiapkan laporan keuangan, memprogram komputer, mendesain gedung kantor, dan menganalisis riset pasar adalah semua contoh keterampilan teknis (BC Campus, 2019). Jenis keterampilan ini sangat penting bagi manajer pengawas, karena mereka bekerja erat dengan karyawan yang memproduksi barang dan/atau jasa organisasi.

Keterampilan hubungan manusia adalah keterampilan interpersonal yang digunakan manajer untuk mencapai tujuan melalui penggunaan sumber daya manusia. Serangkaian keterampilan ini mencakup kemampuan untuk memahami perilaku manusia, berkomunikasi secara efektif dengan orang lain, dan memotivasi individu untuk mencapai tujuan mereka. Memberikan umpan balik positif kepada karyawan, peka terhadap kebutuhan individu, dan menunjukkan kemauan untuk memberdayakan bawahan adalah semua contoh keterampilan hubungan manusia yang baik. Mengidentifikasi dan mempromosikan manajer dengan keterampilan hubungan manusia adalah penting bagi organisasi. Seorang manajer dengan sedikit atau tanpa keterampilan orang bisa menggunakan gaya kepemimpinan otoriter dan mengasingkan karyawan.

Keterampilan konseptual mencakup kemampuan untuk melihat organisasi secara keseluruhan, memahami bagaimana berbagai bagian saling tergantung, dan menilai bagaimana organisasi terkait dengan lingkungan eksternal. Keterampilan ini memungkinkan manajer untuk mengevaluasi situasi dan mengembangkan tindakan alternatif. Keterampilan konseptual yang baik terutama diperlukan untuk manajer di puncak piramida manajemen, di mana perencanaan strategis berlangsung. Ada lima jenis keterampilan manajerial, yaitu: (1) keterampilan teknis; (2) keterampilan konseptual; (3) keterampilan interpersonal dan komunikasi; (4) keterampilan pengambilan keputusan; dan (5) keterampilan diagnostik dan analitik (Katz, 2017; Schein, 2017; Burhanuddin, 1994). Keterampilan manajerial memungkinkan mahasiswa untuk mempertahankan efisiensi dengan cara bagaimana mereka melakukan tugasnya. Mahasiswa harus memiliki keterampilan untuk mengelola orang dan teknologi dengan tujuan pemenuhan tugas mereka secara efektif dan efisien.

\section{Keterampilan Teknis}

Keterampilan ini pada dasarnya melibatkan penggunaan pengetahuan, metode dan teknik dalam melakukan pekerjaan secara efektif. Ini adalah pengetahuan dan keahlian khusus yang digunakan dalam menangani masalah dan kegiatan sehari-hari. Misalnya, insinyur, akuntan, pemrogram komputer, dan analis sistem, semua memiliki keterampilan teknis di bidang mereka dan keterampilan ini diperoleh 
melalui pendidikan dan pelatihan. Keterampilan ini sangat diperlukan pada tingkat manajemen yang lebih rendah dan ketika seseorang beralih ke tingkat manajemen yang lebih tinggi, kepentingan relatif dari keterampilan teknis biasanya berkurang. Ini karena tidak seperti pengawas tingkat pertama, manajer di tingkat yang lebih tinggi kurang memiliki kontak langsung dengan masalah dan kegiatan operasi teknis.

Keterampilan teknis harus dimiliki oleh manajer untuk menyelesaikan tugas organisasi. Ini tidak dimaksudkan untuk bekerja pada mesin, tetapi dapat digunakan untuk penjualan dan pemasaran. Pada dasarnya, keterampilan teknis adalah kemampuan untuk melakukan pekerjaan yang ditugaskan. Keterampilan teknis membantu para manajer tingkat senior dan menengah untuk menggunakan berbagai mesin dan alat. Ini juga membantu mereka menggunakan berbagai prosedur dan teknik. Manajer tingkat rendah harus mahir dengan keterampilan teknis seperti itu untuk memberikan kinerja tinggi karena mereka harus melakukan tugas di lapangan. Keterampilan teknis adalah kecakapan dalam pelaksanaan tugas-tugas tertentu, khususnya keterampilan yang melibatkan metode, teknik khusus, dan peralatan yang terlibat dalam fungsi tertentu, misalnya manufaktur dan teknik. Keterampilan teknis juga mencakup pengetahuan khusus, kemampuan logis, dan penggunaan alat dan teknik yang mahir untuk memecahkan masalah bisnis (Jandaghi, dkk., 2009).

Keterampilan teknis adalah pengetahuan dan kemahiran dalam kegiatan yang melibatkan metode, proses, dan prosedur. Oleh sebab itu, keterampilan teknis melibatkan pekerjaan dengan alat dan teknik khusus. Keterampilan teknis adalah kemampuan untuk menggunakan pengetahuan khusus, prosedur, dan teknik bidang kegiatan. Keterampilan teknis lazim melibatkan pemahaman serta menunjukkan kemahiran dalam aktivitas di suatu tempat kerja tertentu. Keterampilan teknis merupakan pekerjaan yang lazim menggunakan hal-hal, seperti perangkat lunak, operasi sebuah mesin membuat anggaran, atau mempersiapkan presentasi. Keterampilan teknis yang digunakan akan berbeda di setiap tingkat manajemen.

Pemimpin pada level pertama terlibat dalam operasi-operasi nyata organisasi. Pemimpin pada level pertama harus memiliki pemahaman tentang bagaimana produksi dan jasa terjadi dalam organisasi dalam rangka untuk mengarahkan dan mengevaluasi jajaran karyawan. Selain itu, pemimpin pada level pertama perlu keahlian dalam penjadwalan pekerja dan mempersiapkan anggaran. Pemimpin pada level tengah menggunakan keterampilan yang lebih teknis berkaitan dengan perencanaan dan pengorganisiran, dan pemimpin pada level puncak perlu memiliki keterampilan untuk memahami cara kerja keuangan yang kompleks dari organisasi.

\section{Keterampilan Konseptual}

Keterampilan konseptual adalah kemampuan untuk melihat "gambaran besar", untuk mengenali elemen signifikan dalam suatu situasi dan untuk memahami hubungan antara elemen-elemen. Keterampilan konseptual adalah kemampuan untuk mengoordinasikan dan mengintegrasikan semua minat dan kegiatan organisasi. Hal ini membutuhkan memiliki kemampuan untuk memvisualisasikan organisasi secara keseluruhan, untuk membayangkan semua fungsi yang terlibat dalam situasi atau keadaan tertentu, untuk memahami bagaimana bagian-bagiannya bergantung satu sama lain dan mengantisipasi bagaimana perubahan pada bagian mana pun akan mempengaruhi keseluruhan. Kemampuan seorang pemimpin untuk berpikir secara abstrak dan melihat organisasi secara holistik adalah penting. Wujud dari kemampuan konseptual misalnya adalah mengusulkan lini produk atau layanan baru untuk organisasi, mengenalkan teknologi baru ke operasi organisasi, atau melakukan ekspansi.

Keterampilan konseptual adalah kemampuan untuk melihat organisasi secara keseluruhan dan sebagai entitas total serta sistem yang terdiri dari berbagai bagian dan subsistem yang diintegrasikan ke dalam satu unit. Keahlian ini sangat penting bagi eksekutif tingkat atas yang harus menjaga seluruh sistem tetap fokus. Mereka harus memahami kompleksitas organisasi secara keseluruhan, termasuk bagaimana setiap unit organisasi berkontribusi terhadap keberhasilan keseluruhan organisasi. Keterampilan ini umumnya tergantung pada proses berpikir terorganisir yang berkaitan dengan pemahaman berbagai fungsi organisasi, saling ketergantungan mereka dan hubungan organisasi dengan lingkungan luar dalam hal ancaman dan peluang. 
Keterampilan konseptual adalah bakat atau pemahaman manajer untuk pemikiran abstrak untuk menilai seluruh situasi dan mengidentifikasi berbagai keadaan dan untuk meramalkan keadaan bisnis di masa depan. Keterampilan konseptual adalah kemampuan seorang manajer untuk membayangkan organisasi secara keseluruhan, membedakan hubungan timbal balik dan menyadari bagaimana organisasi cocok dengan peradaban, komunitas, dan dunia. Keterampilan konseptual mengeksploitasi kemampuan manusia untuk membentuk konsep (Weick, 1991; 1988; Hidayah, dkk., 2017). Keterampilan tersebut termasuk berpikir kreatif; merumuskan abstraksi, menganalisis situasi yang kompleks, dan menyelesaikan masalah. Keahlian semacam itu membantu tim manajemen untuk memahami penyebab utama masalah dan bukan gejalanya. Mangers yang memiliki penguasaan atas keterampilan ini berada dalam posisi untuk menyelesaikan masalah dan meningkatkan produktivitas organisasi. Ini juga membantu manajer untuk menetapkan tujuan bagi organisasi dan menyusun rencana untuk setiap situasi. Keterampilan konseptual diperlukan oleh manajemen senior karena mereka terlibat dalam perencanaan, pengorganisasian, dan penyelesaian masalah. Dalam bisnis yang diajukan, keterampilan ini diperlukan agar manajemen dapat menjalankan bisnis dengan sukses. Keterampilan konseptual digunakan dalam perencanaan dan berurusan dengan ide-ide dan abstraksi. Kemampuan tersebut memungkinkan manajer untuk membuat keputusan yang baik yang merupakan karakteristik dari semua manajer (Katz, 1955).

\section{Keterampilan Interpersonal dan Komunikasi}

Keterampilan komunikasi adalah suatu keharusan. Orang harus dapat menyampaikan ide dan informasi kepada orang lain dan menerima informasi dan ide dari orang lain secara efektif. Tugas seorang pemimpin adalah mengendalikan bawahan dan memberikan informasi kepada administrator tingkat tinggi tentang apa yang terjadi. Keahlian komunikasi memungkinkan seorang pemimpin untuk melakukannya dengan benar. Sebagian besar waktunya, pekerjaan seorang pemimpin adalah berinteraksi dengan orang-orang di dalam dan di luar organisasi. Kemampuan seorang pemimpin untuk berkomunikasi dengan individu dan kelompok, mengendalikan dan memotivasi para bawahannya adalah keahlian interpersonal dan komunikasi. Seorang pemimpin membutuhkan memiliki keterampilan interpersonal dan komunikasi yang efektif untuk menjaga tanggung jawab yang diberikan kepadanya.

Keterampilan ini adalah kemampuan untuk bekerja dengan orang lain secara kooperatif. Ini melibatkan pemahaman, kesabaran, kepercayaan, dan keterlibatan tulus dalam hubungan interpersonal (Sultoni, dkk., 2018a; Kusmintardjo dan Gunawan, 2017; Sultoni, dkk., 2018b). Ini adalah keterampilan interpersonal dan diperlukan di semua tingkatan manajemen. Orang-orang dengan kemampuan berinteraksi manusia yang baik membangun kepercayaan dan kerja sama ketika mereka memotivasi dan memimpin dan dengan demikian menjadi manajer yang sukses. Keterampilan ini semakin penting karena tempat kerja menjadi semakin beragam secara etnis dan manajer harus sadar dan menjadi adaptif terhadap perbedaan budaya. Lebih jauh, karena bisnis semakin menjadi multinasional dan global, para manajer dituntut untuk mempelajari cara-cara baru untuk berurusan dengan orang-orang di berbagai negara dengan budaya dan sistem nilai yang berbeda.

Memahami tentang keterampilan manusia bagi para manajer untuk mengekstraksi pekerjaan dari karyawan. Peran paling penting bagi manajer adalah mengelola orang secara efektif dalam organisasi dan memberikan hasil terbaik. Keterampilan hubungan manusia juga disebut keterampilan interpersonal. Ini adalah kemampuan untuk bekerja dengan individu. Ini membantu para manajer untuk memahami, berbicara, dan bekerja dengan orang lain. Ini juga membantu para manajer untuk memimpin, mendorong dan mengembangkan kekuatan tim. Keterampilan hubungan manusia diperlukan oleh semua manajer di semua tingkatan manajemen. Semua manajer harus bekerja bersama. Keterampilan ini akan memungkinkan manajer untuk menjadi pemimpin, untuk menginspirasi karyawan untuk melakukan tugas terbaik dan menyelesaikan dengan sukses. Beberapa keterampilan hubungan manusia adalah: kepekaan terhadap orang lain, memperlakukan orang secara adil, mendengarkan dengan sungguhsungguh, berkomunikasi kehangatan, membangun hubungan, memahami perilaku manusia, empati, kebiasaan, anggota tim koperasi, menghindari stereotip orang, merasa nyaman dengan berbagai jenis orang, menyenangkan orang untuk bekerja dengan, memperlakukan orang lain sederajat, berurusan secara efektif dengan konflik, membantu memperjelas kesalahpahaman, dan menciptakan lingkungan interaksi sosial. 
Komunikasi adalah proses penting, yang melibatkan pengorganisasian, pemilihan dan pengiriman simbol dengan cara yang benar untuk memastikan bahwa pendengar memahami dan menciptakan kembali dalam pikirannya sendiri makna yang dimaksud dari komunikator. Komunikasi melibatkan inisiasi makna dalam pendengar, transmisi informasi dan ribuan kemungkinan rangsangan. Keterampilan komunikasi secara kongruen diperlukan di semua tingkatan manajemen. Manajer harus memiliki kemampuan untuk mengomunikasikan rencana dan kebijakan kepada tenaga kerja. Sejalan dengan itu, mereka harus mendengarkan dan memecahkan masalah para pekerja. Mereka harus mempromosikan aliran komunikasi bebas dalam organisasi.

\section{Keterampilan Pengambilan Keputusan}

Tugas seorang pemimpin adalah membuat keputusan yang akan mengarahkan organisasi ke pencapaian tujuan. Keterampilan pengambilan keputusan adalah keterampilan yang membuat seorang pemimpin mampu mengenali peluang dan ancaman dan kemudian memilih tindakan yang sesuai untuk mengatasinya adalah cara yang efisien sehingga organisasi dapat mengambil manfaat bagi mereka (Khan dan Ghouri, 2011; Bafadal, dkk., 2018b; Sobri, dkk., 2018; Nurabadi, dkk., 2018). Seorang pemimpin tidak selalu akan membuat keputusan terbaik. Tetapi seorang pemimpin yang baik paling sering membuat keputusan yang baik dan belajar dari yang buruk. Pengambilan keputusan adalah keterampilan yang dapat meningkat, karena seorang pemimpin mendapatkan lebih banyak pengalaman. Pelatihan atau pendidikan juga merupakan metode yang baik untuk mengembangkan keterampilan pengambilan keputusan seorang pemimpin.

Keterampilan membuat keputusan sangat penting untuk kesuksesan bisnis. Kualitas keputusan menentukan kemampuan dan pemimpin manajer proyek. Manajer harus sering mengambil keputusan dalam pengaturan organisasi. Sebagian besar keputusan ini tidak penting dan dapat dibuat dengan menggunakan "akal sehat". Namun, beberapa keputusan ini berdampak besar pada proyek, anggota tim, atau bisnis secara umum. Untuk kasus-kasus ini, membuat keputusan yang perseptif dan mendalam dapat menghasilkan pilihan yang buruk dengan konsekuensi berbahaya yang signifikan. Untuk meminimalkan konsekuensi negatif, keputusan yang kompleks atau berdampak tinggi harus dibuat menggunakan model pengambilan keputusan yang sistematis. Keterampilan pengambilan keputusan juga dibutuhkan di semua tingkatan manajemen. Meskipun manajemen tingkat atas mengambil keputusan besar tetapi eksekutif tingkat menengah dan bawah harus memiliki untuk mengambil keputusan dalam situasi bisnis yang kritis. Seorang manajer harus memiliki kemampuan untuk mengambil keputusan yang cepat dan benar. Ia juga harus dapat menjalankan keputusannya dengan cerdas. Keberhasilan atau kegagalan seorang manajer tergantung pada ketepatan keputusannya. Beberapa faktor yang membuat keputusan kompleks adalah beberapa alternatif, ketidakpastian yang signifikan, banyak pemangku kepentingan, faktor-faktor yang membuat keputusan berdampak tinggi adalah Konsekuensi finansial, Konsekuensi hidup atau mati, Persepsi Bisnis atau Reputasi. Meningkatkan keterampilan dalam pengambilan keputusan akan membantu manajer untuk menentukan apakah pendekatan intuitif atau analitis harus digunakan.

\section{Keterampilan Diagnostik dan Analitik}

Seorang pemimpin yang baik memiliki keterampilan diagnostik dan analitik. Keahlian diagnostik mengacu pada kemampuan untuk memvisualisasikan respons terbaik terhadap suatu situasi. Keahlian analitis berarti kemampuan untuk mengidentifikasi variabel-variabel kunci dalam suatu situasi. Keahlian diagnostik dan keterampilan analitis seorang pemimpin membantunya mengidentifikasi kemungkinan pendekatan pada suatu situasi (Pertiwi, dkk., 2017; Sudharta, dkk., 2017; Hardika, dkk., 2018). Setelah itu juga membantu seorang pemimpin untuk memvisualisasikan hasil atau hasil pendekatan ini.

Keterampilan ini terdengar mirip dengan keterampilan pengambilan keputusan, tetapi itu adalah keterampilan yang diperlukan untuk membuat keputusan. Keterampilan ini adalah keterampilan yang harus dimiliki seorang pemimpin ideal (Pertiwi, dkk., 2017; Kusumaningrum, dkk., 2018; Agustina, dkk., 2018). Jika seorang pemimpin dilihat cukup dekat, maka akan dapat ditemukan keterampilan ini dengan keterampilan pengambilan keputusan saling terkait dan tak tergantikan. Seorang pemimpin ditunjuk untuk membuat keputusan. Jadi, untuk membuat keputusan, ia perlu mengidentifikasi situasi yang bisa menjadi peluang atau ancaman. 
Pengetahuan konseptual sangat penting untuk ini, karena membantu seorang pemimpin memiliki pemahaman yang lengkap tentang organisasi. Seorang pemimpin tidak dapat memutuskan tanpa mendiagnosis dan menganalisis. Mendiagnosis dan menganalisis situasi diperlukan untuk mengatasi suatu situasi dan untuk ini membutuhkan informasi dan sumber daya (Kusumaningrum, dkk., 2017a; Bafadal, dkk., 2018a). Mengumpulkan informasi dan mengumpulkan sumber daya membutuhkan komunikasi dengan rekan kerja dan orang-orang di luar organisasi.

Dibujuk, dibimbing, dimotivasi, dan dapatkan yang terbaik dari mereka. Seorang pemimpin tidak bisa begitu saja mengambil keputusan dan duduk di kantor (Kusumaningrum, dkk., 2017b); ia perlu memiliki keterampilan teknis untuk melakukan tugas yang ditentukan oleh keputusan. Pemimpin yang baik memiliki semua keterampilan ini, tetapi tidak sepenuhnya benar bahwa semua itu sama pentingnya atau diperlukan untuk pekerjaan yang ditugaskan atau jabatan manajer. Kepentingan relatif dari keterampilan seorang pemimpin ini tergantung pada levelnya dalam hierarki organisasi.

\section{SIMPULAN}

Hasil analisis validitas menyimpulkan bahwa 17 item valid untuk mengukur variabel keterampilan manajerial mahasiswa. Uji reliabilitas terhadap 17 item tersebut menyimpulkan instrumen reliabel, dengan $r_{\text {alpha }}=0,864$. Keterampilan manajerial adalah aspek penting yang perlu dimiliki mahasiswa agar ia dapat hidup di masyarakat dengan harmoni yang tinggi. Kemampuan tersebut sangat dibutuhkan mahasiswa untuk berinteraksi dengan orang lain dan dalam penyelenggaraan organisasi mahasiswa. Keterampilan manajerial adalah kemampuan seseorang dalam melakukan suatu tindakan dan tindakan tersebut merupakan hasil dari sebuah pemikiran terlebih dahulu. Jika mengacu pada konsep tersebut, maka keterampilan manajerial adalah suatu tindakan yang mencerminkan apa yang dipikirkan oleh seseorang.

\section{DAFTAR RUJUKAN}

Agustina, N. E., Sumarsono, R. B., \& Gunawan, I. (2018). Implementation of School and Community Relationship Techniques (A Case Study in SDN Karangbesuki 2 Malang, Indonesia). In 1st International Conference on Early Childhood and Primary Education (ECPE 2018). Atlantis Press.

Bafadal, I., Juharyanto, J., Nurabadi, A., \& Gunawan, I. (2018a). Principal Leadership and its Relationship with Student Learning Achievements: A Regression Analysis. In 3rd International Conference on Educational Management and Administration (CoEMA 2018). Atlantis Press.

Bafadal, I., Nurabadi, A., \& Gunawan, I. (2018b). The Influence of Instructional Leadership, Change Leadership, and Spiritual Leadership Applied at Schools to Teachers' Performance Quality. In International Conference on Education and Technology (ICET 2018). Atlantis Press.

BC Campus. (2019). Management and Leadership in Today's Organizations. (Online). (https://opentextbc.ca/ businessopenstax/chapter/managerial-skills/), diakses 2 Agustus 2019.

Burhanuddin. (1994). Analisis Administrasi Manajemen dan Kepemimpinan Pendidikan. Jakarta: PT Bumi Aksara. Gunawan, I. (2013). Statistika untuk Kependidikan Sekolah Dasar. Yogyakarta: Penerbit Ombak Yogyakarta.

Gunawan, I. (2016). Pengantar Statistika Inferensial. Jakarta: Rajawali Pers.

Gunawan, I., Kusumaningrum, D. E., Triwiyanto, T., Zulkarnain, W., Nurabadi, A., Sanutra, M. F. A., ... \& Yuantika, E. A. F. (2018a). Hidden Curriculum and Character Building on Self-Motivation based on K-means Clustering. In 2018 4th International Conference on Education and Technology (ICET) (pp. 32-35). IEEE.

Gunawan, I., Kusumaningrum, D. E., Triwiyanto, T., Zulkarnain, W., \& Nurabadi, A. (2018b). Hidden Curriculum and its Relationship with the Student Character Building. In 3rd International Conference on Educational Management and Administration (CoEMA 2018). Atlantis Press.

Gunawan, I., Kusumaningrum, D. E., Triwiyanto, T., Zulkarnain, W., \& Nurabadi, A. (2018c). Pengaruh Kurikulum Tersembunyi terhadap Motivasi Diri Mahasiswa. Prosiding Seminar Nasional Pendidikan, Tema: Mendidik Cerdas Generasi Digital, Fakultas Ilmu Pendidikan Universitas Negeri Malang, Malang, 4 Oktober 2018, hlm. 90-97. 
Hadi, S., Gunawan, I., \& Dalle, J. 2018. Statistika Inferensial: Teori dan Aplikasinya. Jakarta: Rajawali Pers.

Hardika, H., Aisyah, E. N., \& Gunawan, I. (2018). Facilitative Learning to Improve Student Learning Creativity. In 3rd International Conference on Educational Management and Administration (CoEMA 2018). Atlantis Press.

Harmini, S., Kartini, H., \& Gunawan, I. (2017). Filsafat dan Teori Pendidikan. Malang: Penerbit Universitas Negeri Malang, Penerbit UM Press.

Hidayah, N., Hardika, Hotifah, Y., Susilawati, S. Y., \& Gunawan, I. (2017). Psikologi Pendidikan. Malang: Penerbit Universitas Negeri Malang, Penerbit UM Press.

Jandaghi, G., Martin, H. Z., Khanifar, H., \& Kiaei, H. (2009). The Study on the Relationship between Management Skills of Managers and Organizational Learning in Rah-Shahr International Corporation. International Business Management, 3(4), 69-74.

Katz, R. L. (1955). Skills of an Effective Administrator. Harvard Business Review, 33(1), 33-42.

Katz, R. L. (2017). Skills of an Effective Administrator. Harvard: Harvard Business School Press.

Khan, I. A., \& Ghouri, A. M. (2011). Managerial Skills and Organizational Learning in SMEs of Pakistan. Indian Journal of Commerce \& Management Studies, 2(4), 61-69.

Kholiq, A. (2011). Pengantar Manajemen. Semarang: Rafi Sarana Perkasa.

Kusmintardjo, \& Gunawan, I. 2017. Manajemen Layanan Khusus. Malang: Penerbit Universitas Negeri Malang, Penerbit UM Press.

Kusumaningrum, D. E., Sumarsono, R. B., \& Gunawan, I. (2017a). Pemberdayaan Tenaga Administrasi Sekolah Menengah Pertama Berbasis Pesantren. In Prosiding Seminar Nasional Pendidikan Sinergitas Keluarga, Sekolah, dan Masyarakat dalam Penguatan Pendidikan Karakter, Fakultas Ilmu Pendidikan Universitas Negeri Malang, Malang (Vol. 16, pp. 127-138).

Kusumaningrum, D. E., Sumarsono, R. B., \& Gunawan, I. (2017b). Problematika Pemberdayaan dan Pengembangan Sumber Daya Manusia di Sekolah Menengah Pertama Berbasis Pesantren. Ilmu Pendidikan: Jurnal Kajian Teori dan Praktik Kependidikan, 2(2), 139-150.

Kusumaningrum, D. E., Sumarsono, R. B., \& Gunawan, I. (2018). Teachers Empowerment of Pesantren-Based Junior High School East Java Province Indonesia. Journal of Social Sciences and Humanity Studies, 4(3), 29-33.

Nurabadi, A., Sucipto, S., Juharyanto, J., \& Gunawan, I. (2018). The Implementation of Education Management Standards in the School Laboratory State University of Malang for Improving Educational Quality. In 3rd International Conference on Educational Management and Administration (CoEMA 2018). Atlantis Press.

Pertiwi, A. K., Cahyani, S. S. A., Diana, R. C., \& Gunawan, I. (2017). Kepemimpinan Berbasis Nilai dan Etika: Suatu Kajian Interaksi Simbolik Kyai dan Santri. In Prosiding Seminar Nasional Pendidikan: Sinergitas Keluarga, Sekolah, dan Masyarakat dalam Penguatan Pendidikan Karakter, Universitas Negeri Malang, Malang (Vol. 16, pp. 1-9).

Pertiwi, A. K., Cahyani, S. S. A., Diana, R. C., \& Gunawan, I. (2018). The Leadership of Kyai: A Descriptive Study. In 3rd International Conference on Educational Management and Administration (CoEMA 2018). Atlantis Press.

Schein, E. H. (2017). Organizational Culture and Leadership. New York: Jossey-Bass.

Sobri, A. Y., Bafadal, I., Nurabadi, A., \& Gunawan, I. (2018). Development of Mentoring Modules Based on Self-Reflection for Beginner Principal. In 3rd International Conference on Educational Management and Administration (CoEMA 2018). Atlantis Press.

Sudharta, V. A., Mujiati, M., Rosidah, A., \& Gunawan, I. (2017). Gaya Kepemimpinan Kepala Sekolah dalam Perspektif Psikologi. JMSP: Jurnal Manajemen dan Supervisi Pendidikan, 1(3), 208-217.

Sultoni, Gunawan, I., \& Sari, D. N. (2018b). The Internalization of Character Values to Students: A Descriptive Study. In International Conference on Education and Technology (ICET 2018). Atlantis Press.

Sultoni, S., Gunawan, I., \& Ningsih, S. O. (2018a). Descriptive Study of Efforts Integrates Character Values to Students. In 3rd International Conference on Educational Management and Administration (CoEMA 2018). Atlantis Press.

Weick, K. E. (1988). Enacted Sensemaking in Crisis Situations. Journal of Management Studies, 25(4), 305-317.

Weick, K. E. (1991). The Non Traditional Quality of Organization Al Learning. Organization Science, 2(1), 116124. 